\title{
Multilayer Perceptron untuk Prediksi Sessions pada Sebuah Website Journal Elektronik
}

\author{
Aji Prasetya Wibawa ${ }^{\mathrm{a}, 1}$, Widya Lestari ${ }^{\mathrm{a}, 2}$, Agung Bella Putra Utama ${ }^{\mathrm{a}, 3}$, Irzan Tri Saputra ${ }^{\mathrm{a}, 4}$, Zahra \\ Nabila Izdihar ${ }^{\mathrm{a}, 5}$ \\ ${ }^{a}$ Universitas Negeri Malang, Jl. Semarang No. 5, Malang 65145, Indonesia \\ ${ }^{1}$ aji.prasetya.ft@um.ac.id; ${ }^{2}$ lestariwidya792@gmail.com; ${ }^{3}$ agungbpu02@gmail.com; ${ }^{4}$ saputrairzan@gmail.com; \\ 5zahra.informatics@gmail.com;
}

\begin{tabular}{|c|c|}
\hline INFORMASI ARTIKEL & ABSTRAK \\
\hline $\begin{array}{ll}\text { Diterima } & : 04-10-2020 \\
\text { Direvisi } & : 01-11-2020 \\
\text { Diterbitkan } & : 31-12-2020\end{array}$ & \multirow{2}{*}{$\begin{array}{l}\text { Peramalan session website journal dilakukan untuk pendukung } \\
\text { pengambilan keputusan dalam rangka meningkatkan kualitas dan nilai } \\
\text { akreditasi pada website jurnal. Data sessions dianalisis berdasarkan } \\
\text { pergerakan pola data time series menggunakan metode multilayer } \\
\text { perceptron. Karakteristik yang dimiliki oleh multilayer perceptron yaitu } \\
\text { keunggulan dalam penentuan nilai bobot yang lebih baik daripada metode } \\
\text { lain, multilayer perceptron dapat digunakan tanpa pengetahuan sebelumnya } \\
\text { dan algoritma dapat diimplementasikan dengan mudah serta mampu } \\
\text { menyelesaikan masalah linear dan nonlinear sehingga nilai peramalan } \\
\text { menjadi lebih baik. Penelitian menggunakan berbagai persentase data train } \\
\text { dan test. Perbandingan data train dan test yang memiliki nilai terbaik adalah } \\
\text { 80\% data train dan } 20 \% \text { data test dengan learning rate } 0.4 \text { dan arsitektur } 2- \\
\text { 1-1. Hasil evaluasi model diperoleh nilai MSE dan RMSE, } 0.015357 \text { dan } \\
\text { 0.123999 untuk training set serta, 0.018996 dan } 0.137826 \text { untuk MSE dan } \\
\text { RMSE dari test set. Waktu eksekusi yang dibutuhkan untuk melakukan } \\
\text { peramalan adalah } 580.0651 \text { second atau } 9.667751 \text { menit. }\end{array}$} \\
\hline $\begin{array}{l}\text { Kata Kunci: } \\
\text { Multilayer Perceptron } \\
\text { Prediksi } \\
\text { Sessions } \\
\text { Website Journal }\end{array}$ & \\
\hline & $(\mathrm{cc}) \overline{\mathrm{EY}-\mathrm{NC}}$ \\
\hline
\end{tabular}

\section{Pendahuluan}

Forecasting adalah salah satu metode data mining yang digunakan untuk memperkirakan sesuatu yang belum terjadi [1]. Peramalan diperlukan dalam berbagai situasi seperti membuat perencanaan terkait kegiatan usaha dalam beberapa periode tertentu [2]. Fungsi dari peramalan adalah penunjang dalam pengambilan keputusan. Keputusan yang baik didasarkan atas pertimbangan terhadap sesuatu yang terjadi pada saat keputusan itu diambil [3].

Ada banyak penelitian menggunakan metode forecasting. Berbagai penelitian yang menggunakan metode forecasting antara lain, metode ARIMA untuk peramalan bahan baku produk plastik berbasis data pendapatan [4], metode ARMA untuk peramalan angin [5], metode neural network untuk power system short-term load forecasting [6],[7], metode exponential smoothing untuk kombinasi konsumsi suku cadang [8], [9], metode radial base function (RBF) untuk peramalan kecepatan angin [10], multilayer perceptron untuk analisis properti Jordan Oil Shale [11], dan lain-lain. Setiap metode forecasting memiliki kelebihan dan kekurangan sendiri apabila diimplementasikan pada suatu kasus tertentu.

Metode forecasting yang sering digunakan dalam penelitian adalah multilayer perceptron neural network (MLP) [12]. Karakteristik yang dimiliki oleh MLP yaitu keunggulan dalam penentuan nilai bobot yang lebih baik daripada metode lain [13], MLP dapat digunakan tanpa pengetahuan sebelumnya dan algoritma dapat diimplementasikan dengan mudah [12] serta mampu menyelesaikan masalah linear dan nonlinear [14]. Berdasarkan dengan karakteristik yang dimiliki oleh MLP membuat nilai peramalan menjadi lebih baik.

Metode MLP akan digunakan untuk melakukan peramalan terhadap sessions dari suatu website jurnal. Sessions adalah serangkaian halaman web yang ditelusuri pengguna dalam single access. Identifikasi sessions dapat didefinisikan sebagai satu set halaman yang dikunjungi oleh pengguna yang sama dalam durasi satu kunjungan tertentu ke situs web [15]. Tujuan identifikasi sessions adalah membagi akses halaman setiap pengguna sekaligus menjadi sessions individual [16]. Seorang pengguna dapat memiliki sessions tunggal atau ganda selama suatu periode tertentu. 
Pada bagian II, akan menjelaskan metode penelitian untuk menyelesaikan permasalahan penelitian. Pada bagian III, mendeskripsikan tentang hasil penelitian dan pembahasan. Pada bagian terakhir kesimpulan dari penelitian.

\section{Metode}

\section{A. Desain Penelitian}

Pengolahan data menggunakan metode MLP dilakukan dengan tahapan sesuai dengan Gambar 1.

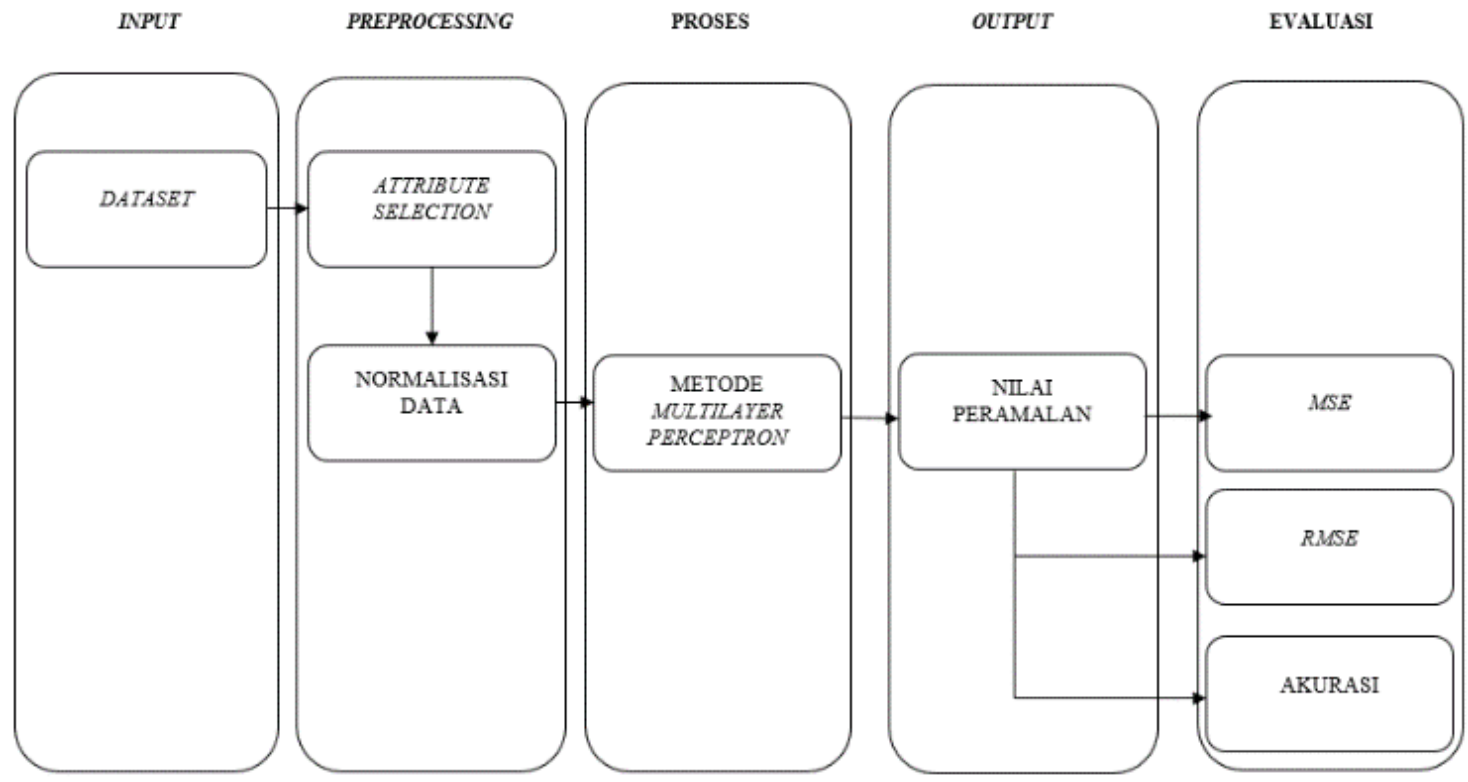

Gambar 1. Desain Penelitian

\section{B. Dataset}

Data yang digunakan dalam penelitian adalah sessions, terhitung mulai tanggal 01 Januari 2018 sampai 31 Desember 2018. Data penelitian diperoleh melalui situs web terpercaya yaitu https://statcounter.com/ yang bertugas untuk mengolah data aktifikas website journal dari salah satu Universitas yang ada di Indonesia. Aktifitas pengguna website journal akan dijadikan suatu laporan statistik. Penelitian ini menggunakan 3 atribut yaitu data $t$ (data sekarang), $t-1$ (data 1 hari sebelumnya pada periode t) dan $t-7$ (data 7 hari sebelumnya pada periode t). Total instance yang digunakan terdiri dari 358 instances.

\section{Attribute Selection}

Attribute selection atau feature selection bertujuan untuk memilih fitur yang berpengaruh (fitur optimal) dan mengesampingkan fitur yang tidak berpengaruh[17]. Attribute selection tidak memiliki wewenang yang terkait dengan pemberian atau pembuatan model. Attribute selection sering ditempatkan pada tahap preprocessing data [18]. Attribute selection dalam penelitian ini dilakukan dengan uji autokorelasi.

Uji autokorelasi dilakukan dengan mengguna fungsi $=\operatorname{CORREL}(\operatorname{array} 1$, array 2$)$ yang terdapat pada Microsoft Excel. array 1 untuk data $t$ dan array 2 untuk data yang akan dilakukan uji autokorelasi. Uji autokorelasi dilakukan pada $t-1$ hingga $t-7$ terhadap $t$. Hubungan autokorelasi akan ditentukan berdasarkan nilai dari variabel $\rho$. Bila nilai $\rho=0$ maka, tidak ada korelasi sedangkan, bila nilai $\rho$ mendekati 1 maka, dikatakan memiliki korelasi yang tinggi [19]. Nilai $\rho$ memiliki kriteria seperti yang ditampilkan pada Tabel 1 .

Tabel 1. Kriteria Uji Autokorelasi

\begin{tabular}{cl}
\hline $\boldsymbol{\rho}$ & Keterangan \\
\hline $0,00-0,199$ & Memiliki hubungan yang sangat lemah \\
$0,20-0,399$ & Memiliki hubungan yang lemah \\
$0,40-0,599$ & Memiliki hubungan yang sedang \\
$0,60-0,799$ & Memiliki hubungan yang sangat kuat \\
$0,80-1,000$ & \\
\hline
\end{tabular}


D. Normalisasi Data

Normalisasi data dilakukan untuk mempertahankan variasi prediksi dan peramalan yang besar [20]. Konsep dasar normalisasi data diperlukan untuk memberikan range yang lebih dekat. Teknik normalisasi data MinMax merupakan teknik yang popular dibandingan dengan teknik yang lain[12].

Normalisasi min-max dipilih karena menyediakan linear transformation pada data original range dan memiliki tingkat kesalahan yang kecil dibandingkan dengan metode yang lain [21]. Range value berada antara 0 dan 1. Proses penyelesaian normalisasi data dilakukan sesuai dengan [22].

$$
X_{i(\text { norm })}=\frac{X_{i}-X_{\min }}{X_{\max }-X_{\min }}
$$

$X_{i(\text { norm })}$ adalah hasil normalisasi, $X_{i}$ adalah data yang akan dinormalisasi, $X_{\min }$ adalah nilai minimal dari keseluruhan data, dan $X_{\max }$ adalah nilai maksimal dari keseluruhan data.

\section{E. Peramalan dengan Menggunakan Multilayer Perceptron}

Multilayer perceptron tergolong dalam feed-forward network [23]. Model multilayer perceptron tersusun dari beberapa lapisan node yang terdiri dari input layer, hidden layer dan output layer. Penentuan elemen multilayer perceptron sangat mempengaruhi kinerja jaringan sehingga, harus dipertimbangkan dengan hatihati [24]. Elemen dari multilayer perceptron terdiri dari, arsitektur jaringan, algoritma pambelajaran dan fungsi aktivasi. Penentuan arsitektur jaringan akan bergantung pada data. Banyak literatur menyatakan bahwa tidak ada aturan umum yang mengatur terkait penentuan arsitektur yang baik, banyak arsitektur harus diperiksa untuk hasil yang benar dengan teknik trial and error [24], [25].

Node dalam arsitektur jaringan akan terhubung lurus mulai dari node pada input layer terhubung ke node pada hidden layer dan node pada hidden layer akan terhubung ke node pada output layer. Setiap node yang terhubung memiliki bobot masing-masing dengan nilai yang sama atau bisa berbeda karena bobot awal ditentukan secara random.

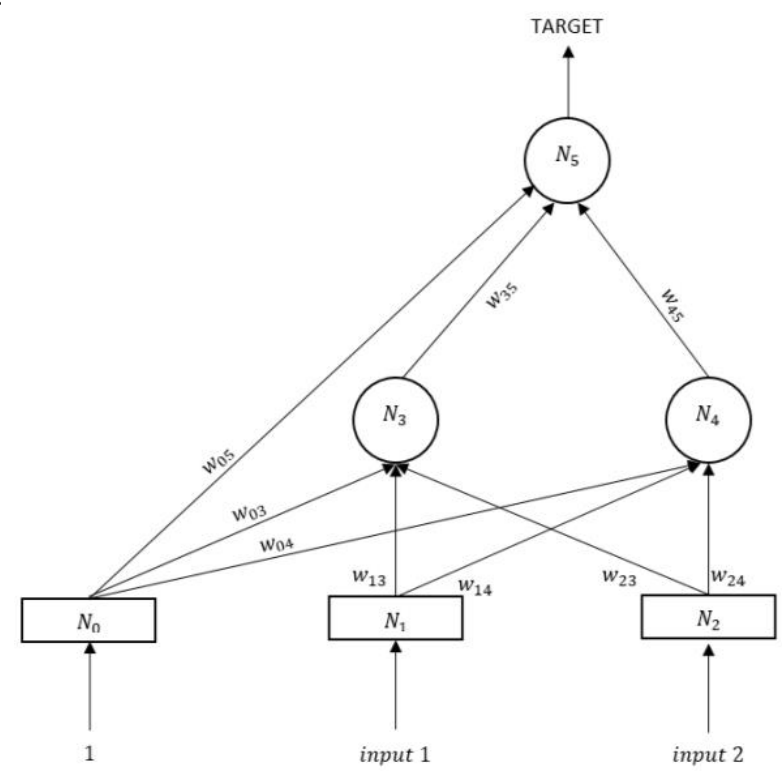

Gambar 2. Salah Satu Arsitektur Multilayer Perceptron

Gambar 2 menjelaskan salah satu arsitektur yang digunakan dalam penelitian. Simbol $N$ menyatakan node untuk setiap layer. Simbol $N_{1}$ dan $N_{2}$ adalah node untuk input layer. $N_{1}$ berperan sebagai input 1 yang diisi oleh nilai $t-1 . N_{2}$ berperan sebagai input 2 yang diisi oleh nilai $t-7$. Nilai $N_{0}$ tidak menggunakan data dari dataset, karena node tersebut adalah node untuk bias dengan nilai awal 1. Nilai 1 yang ada di arsitektur bias adalah konstanta [11]. Simbol $N_{3}$ dan $N_{4}$ adalah node untuk hidden layer dan $N_{5}$, node untuk output layer. Bobot pada setiap node yang terhubung disimbolkan dengan $w$. Penomoran simbol untuk $w$ yaitu, nomor pertama adalah nomor node awal sedangkan, nomor kedua adalah nomor dari node tujuan.

Algoritma pembelajaran pada multilayer perceptron dilakukan sesuai dengan [26][27] sebagai berikut : Langkah 0 (input):

- Input data pelatihan ke jaringan.

Langkah 1 (inisialisasi):

- Melakukan inisialisasi bobot dengan nilai acak yang kecil. 
- Mengatur parameter seperti, learning rate dan momentum coefficient.

Langkah 2 (training loop):

- Menerapkan pola input network ke input layer.

Langkah 3 (forward propagation):

- Menyebarkan sinyal forward melalui jaringan.

- Menghitung network output vector.

Langkah 4 (Menghitung output error):

- Menghitung error pada setiap output, perbedaan antara target yang diinginkan dan network output.

Langkah 5 (error backpropagation):

- Menyebarkan error backward untuk menyesuaikan bobot dengan cara meminimalkan error.

Langkah 6 (satu loop iteration):

- Memeriksa apakah seluruh data telah digunakan.

- Mengulang langkah ke dua dengan menggunakan langkah 5 untuk seluruh training dataset.

Penelitian terhadap peramalan sessions menggunakan MLP dilakukan sebanyak 324 kali percobaan untuk berbagai perbandingan train dan test, arsitektur jaringan dan learning rate. Pengujian dilakukan dengan mengubah jumlah data train dan test, learning rate dan arsitektur jaringan.

Persentase data train dan test yang dilakukan dalam penelitian terdiri dari 10\%, 20\%, 30\%, 40\% 50\% 60\%, 70\%, 80\%, dan 90\% data train. Penggunaan berbagai variasi persentase data train dan test bertujuan untuk menemukan jumlah data terbaik untuk peramalan session. Epoch maksimum yang digunakan adalah 50000 untuk masing-masing data input. Learning rate yang akan digunakan adalah 0,1 sampai 0,9 dengan selisish untuk setiap learning rate adalah 0.1 [28].

Peramalan sessions mengimplementasikan 4 jenis arsitektur yang memiliki 1 input layer-1 hidden layer-1 output layer [29] terdiri dari 2 node input layer-1 node hidden layer-1 node output layer (2-1-1), 2 node input layer-2 node hidden layer- 1 node output layer (2-2-1), 2 node input layer-3 node hidden layer- 1 node output layer (2-3-1) [26],[30], dan 2 node input layer-4 node hidden layer- 1 node output layer (2-4-1)[31].

\section{F. Evaluasi}

Evaluasi hasil peramalan dilakukan dengan menggunaan MSE dan RMSE untuk setiap pengujian data training dan test. Evaluasi dilakukan untuk memverifikasi keefektifan dan keakuratan model yang diusulkan. Nilai akurasi dari MSE dan RMSE akan dibandingkan dan dipilih metode evaluasi terbaik. Proses perhitungan dilakukan sesuai dengan [22], [28].

$$
\begin{aligned}
& \text { Mean Square Error }(M S E)=\frac{1}{N} \sum_{t=1}^{N} e_{t}^{2} \\
& \text { Root Mean Square Error }(R M S E)=\sqrt{\frac{\sum_{t=1}^{N} e_{t}^{2}}{N}}
\end{aligned}
$$

Nilai error yang diperoleh menggunakan MSE dan RMSE akan digunakan untuk menghitung akurasi. Akurasi yang diperoleh dari MSE dan RMSE akan dibandingkan. Tujuan Pembandingan guna mengetahui akurasi terbaik yang dihasilkan dari kedua metode tersebut. Persentase data train dan data test pada grafik akurasi akan dinyatakan sebagai nilai 1 hingga 9. Nilai yang terdapat pada grafik nilai akurasi memiliki keterangan sesuai dengan Tabel 2.

Tabel 2. Keterangan Persentase Data Train dan Test untuk Grafik Akurasi

\begin{tabular}{cl}
\hline Nilai & Keterangan \\
\hline 1 & 10\% Data Train, 90\% Data Test \\
3 & $30 \%$ Data Train, 80\% Data Test \\
4 & $40 \%$ Data Train, 70\% Data Test \\
5 & $50 \%$ Data Test \\
6 & $60 \%$ Data Train, 50\% Data Test \\
7 & $70 \%$ Data Train, 30\% Data Test \\
8 & $80 \%$ Data Test \\
9 & $90 \%$ Data Train, $20 \%$ Data Test $10 \%$ Data Test \\
\hline
\end{tabular}

\section{Hasil dan Pembahasan}

Hasil uji autokorelasi sangat menuntukan dalam peramalan sessions dengan menggunakan MLP. Pemilihan atribut yang kurang tepat untuk masukan model akan mempengaruhi hasil peramalan. Pada penelitian ini nilai $\rho$ tertinggi yang dihasilkan adalah t- 1 dan t-7 dengan nilai 0.670103 dan 0.630831 . Nilai $\rho$ yang dihasilkan dalam penelitian memiliki hubungan yang kuat terhadap t yang dapat dilihat pada Tabel 3.

Tabel 3. Hasil Uji Autokorelasi 


\begin{tabular}{cc}
\hline Variabel Uji Autokorelasi terhadap $t$ & $\rho$ \\
\hline$(t-1)$ & 0.670103 \\
$(t-2)$ & 0.520902 \\
$(t-3)$ & 0.440526 \\
$(t-4)$ & 0.434863 \\
$(t-5)$ & 0.454625 \\
$(t-6)$ & 0.568469 \\
$(t-7)$ & 0.630831 \\
\hline
\end{tabular}

Tabel 4 merupakan tabel hasil normalisasi data target dan data input sebanyak 4 instance data awal pada dataset. Gambar 3 merupakan sampel data input untuk waktu 1 bulan sedangkan, Gambar 4 adalah sampel data target.

Tabel 4. Data Input dan Target

\begin{tabular}{ccc}
\hline & Input Jaringan & \multicolumn{2}{c}{ Target Jaringan } \\
\hline$t-1$ & $t-7$ & $t$ \\
0.9333333333 & 0.7857142857 & 1 \\
0.6 & 0.9642857143 & 0.8214285714 \\
\\
\hline
\end{tabular}

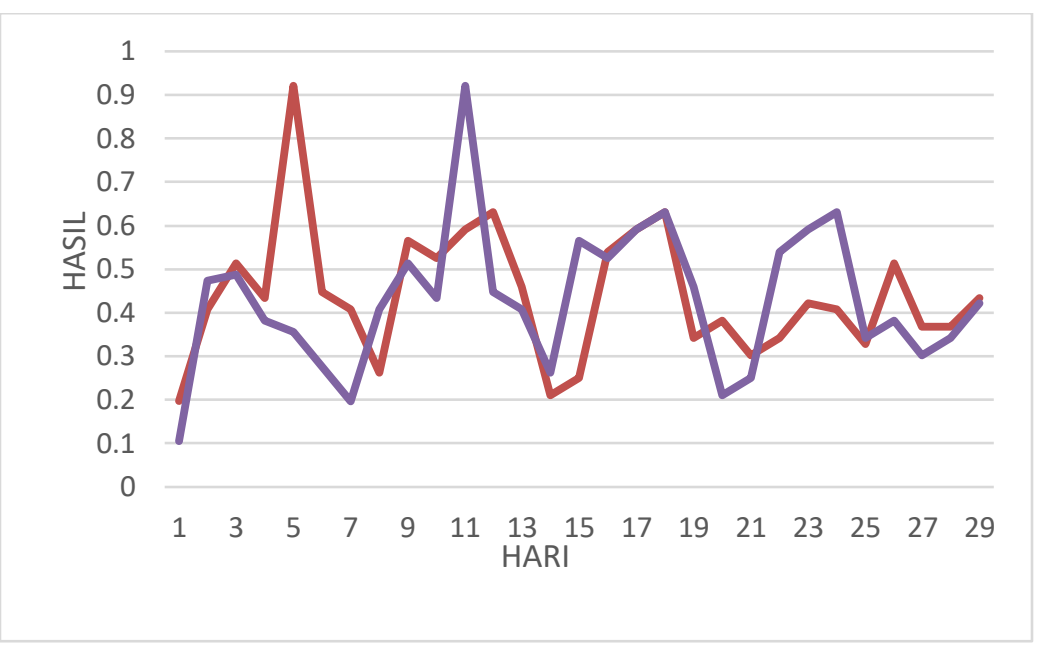

Keterangan : Data $t-1=$ Data $t-7$

Gambar 3. Grafik Data Input

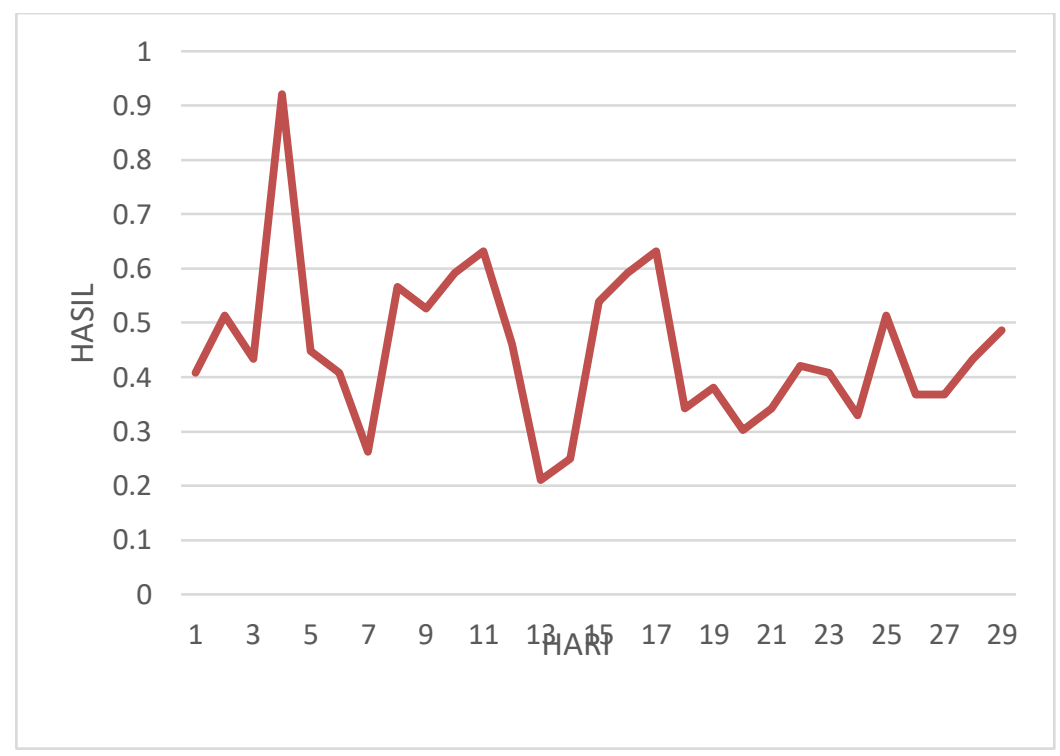

Gambar 4. Grafik Data Target 
Proses memperoleh nilai peramalan terbaik membutuhkan waktu yang cukup lama. Penyelesaian peramalan membutuhkan waktu sekitar 2 bulan. Selama proses penelitian ditemukan faktor-faktor yang dapat mempengaruhi nilai peramalan. Salah satu faktor yang mempengaruhi nilai peramalah adalah kondisi hardware yang digunakan untuk mengeksekusi model. Apabila hardware yang digunakan menjalankan berbagai program ketika melakukan pengeksekusian peramalan maka, waktu eksekusi akan lama. Jadi, proses peramalan harus dilakukan dengan kondisi hardware yang hanya menjalankan model peramalan MLP. Waktu pengeksekusian model peramalan selain dipengaruhi oleh hardware juga dipengaruhi oleh jumlah dari data train dan data test.

Persentase data train yang kecil di awal-awal percobaan model menghasilkan waktu eksekusi yang kecil yaitu 91.20220971 seconds atau 1.52 menit. Semakin lama proses pengeksekusian model berlangsung waktu yang dihasilkan juga semakin besar. Waktu terlama yang dibutuhkan untuk melakukan pengeksekusian model adalah 851.28556947 seconds atau 14.188 menit. Teori awal yang menyatakan bahwa nilai learning rate kecil akan membutuhkan waktu eksekusi yang lama dengan hasil peramalan terbaik tidak terbukti dalam penelitian ini. Nilai learning rate kecil tidak selalu menghasilkan nilai peramalan yang baik dan waktu eksekusi yang rendah begitu juga sebaliknya.

Tabel 5 dan Tabel 6 menampilkan error dari hasil peramalan data train dan data test yang diperoleh dari selisih antara data target dan data hasil peramalan. Rata-rata error yang dihasilkan antara peramalan data train dan data test menunjukan bahwa error pada data train lebih kecil dari data test. Hasil tersebut dipengaruhi adanya proses pelatihan terlebih dahulu pada data train sedangkan, data test tidak melewati proses tersebut.

Dalam kasus ini error tolerance tidak diberikan pada model sehingga penentuan hasil peramalan ditentukan dari jumlah epoch. Selama penelitian, tiga nilai epoch telah diberikan pada model. Nilai epoch terdiri dari 10000, 20000 dan 50000. Pada nilai epoch 10000 nilai error peramalan tergolong besar, sehingga digunakan epoch 20000. Penggunaan nilai epoch 20000 dalam percobaan menghasilkan nilai peramalan yang cenderung lebih baik daripada epoch 10000. Epoch 50000 yang diberikan pada model mengalami perubahan nilai peramalan yang cukup besar. Nilai peramalan yang dihasilkan pada epoch 50000 jauh lebih baik daripada epoch 10000 dan epoch 20000. Sedangkan nilai error yang dihasilkan epoch 50000 stabil dan tidak mengalami perubahan nilai. Selain ketiga nilai yang disebutkan diatas epoch 100000 juga pernah digunakan pada penelitian. Hasil peramalan menggunakan epoch 100000 menghasilkan nilai error yang kecil seperti pada epoch 50000. Nilai error perhenti mengalami perubahan di nilai epoch kurang dari 50000 dan lebih dari 20000.

Tabel 5. Hasil Peramalan Data Train

\begin{tabular}{ccc}
\hline Data Target & Ramalan Data Train & Error \\
\hline 0.40789473 & 0.4165182 & -0.00862347 \\
0.5131579 & 0.48795533 & 0.02520257 \\
0.4342105 & 0.6066792 & -0.1724687 \\
0.92105263 & 0.58910716 & 0.33194547 \\
\hline
\end{tabular}

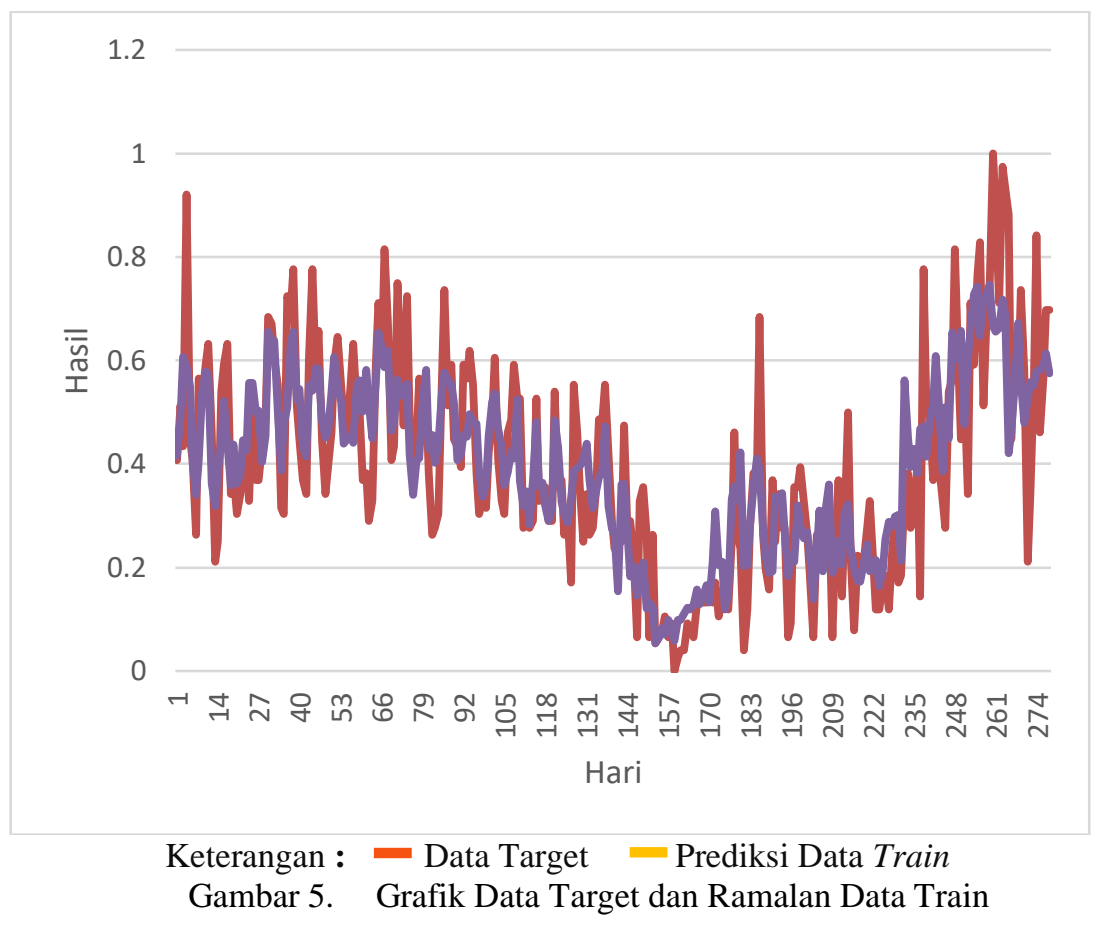




\begin{tabular}{ccc} 
& Tabel 6. & Hasil Peramalan Data Test \\
\hline Data Target & Ramalan Data Train & Error \\
\hline 0.39473683 & 0.39485264 & -0.000115881 \\
0.55263156 & 0.3746122 & 0.17801936 \\
0.31578946 & 0.42650282 & -0.11071336 \\
0.5131579 & 0.55589926 & -0.04274136 \\
\hline
\end{tabular}

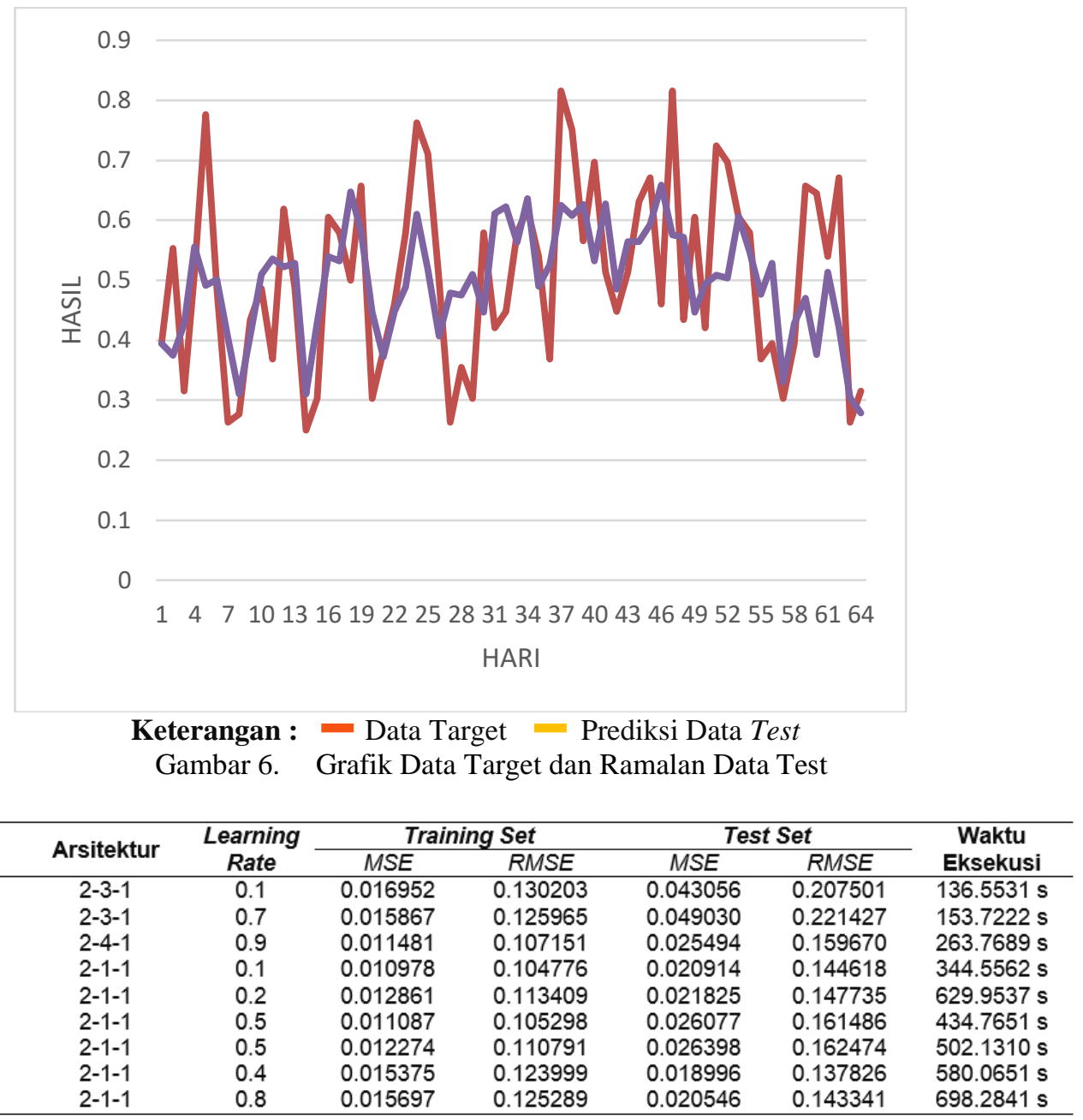

Gambar 7. Hasil Penelitian dengan Nilai Error Tertinggi

Gambar 7 menampilkan nilai peramalan terbaik dari setiap persentase data train dan data test. Perbandingan data train dan test yang memiliki nilai terbaik dari keseluruhan percobaan adalah $80 \%$ data train. Jumlah data yang digunakan adalah 287 data untuk data train dan 71 data untuk data test. Berdasarkan persentase nilai train dan test, nilai peramalan terbaik diperoleh dengan learning rate 0.4 dan arsitektur 2-1-1. Hasil evaluasi model diperoleh nilai MSE dan RMSE, 0.015357 dan 0.123999 untuk training set serta, 0.018996 dan 0.137826 untuk MSE dan RMSE dari data test. Akurasi yang dihasilkan dari nilai MSE jauh lebih tinggi dibandingkan dengan RMSE. Model peramalan terbaik menghasilkan 98.1004\% untuk MSE dan $86.2174 \%$ untuk RMSE. Waktu eksekusi yang dibutuhkan untuk melakukan peramalan adalah 580.0651 second atau 9.667751 menit.

Gambar 8 dan Gambar 9 menampilkan grafik nilai akurasi tertinggi untuk setiap persentase data train dan data test. Nilai akurasi berdasarkan MSE cenderung memiliki nilai akurasi diatas 95\%. Nilai akurasi yang dibentuk dari nilai RMSE memiliki rentang nilai diantara 77\% hingga 86\%. Berdasarkan dengan percobaan yang telah dilakukan akurasi dari MSE memiliki nilai lebih tinggi dari RMSE. Kondisi demikian dilatarbelakangi oleh penggunaan akar $(\sqrt{ })$ untuk menghitung nilai error pada RMSE. 


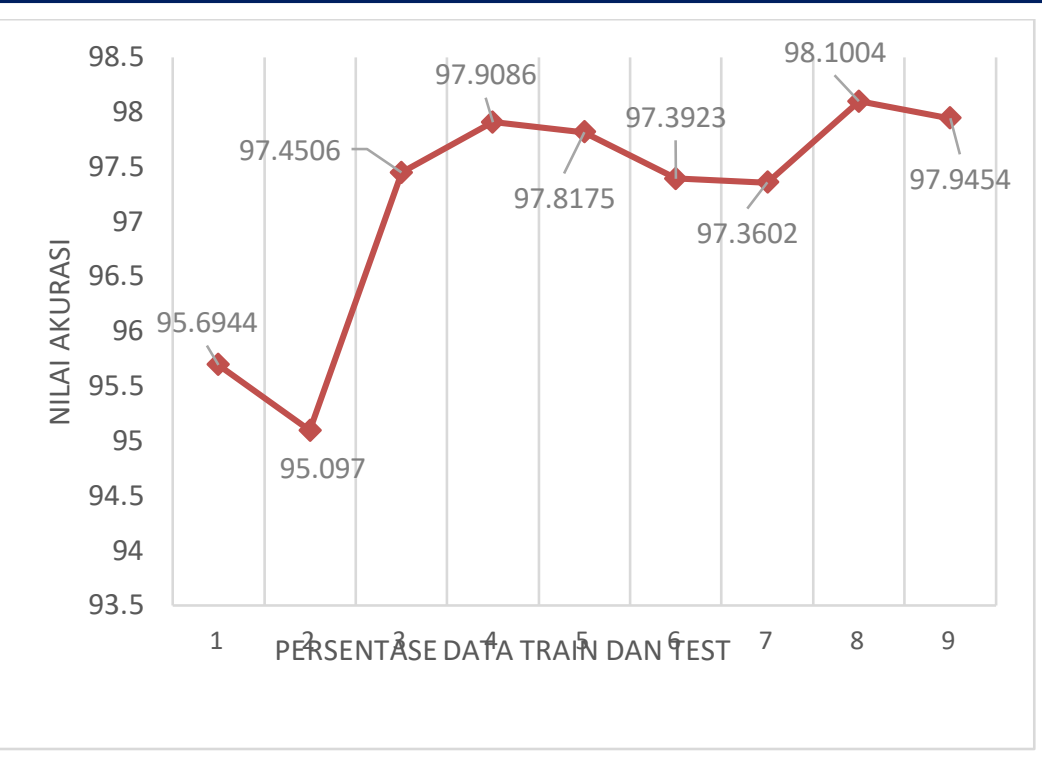

Gambar 8. Grafik Nilai Akurasi Tertinggi dengan MSE untuk Setiap Persentase Data Train dan Test

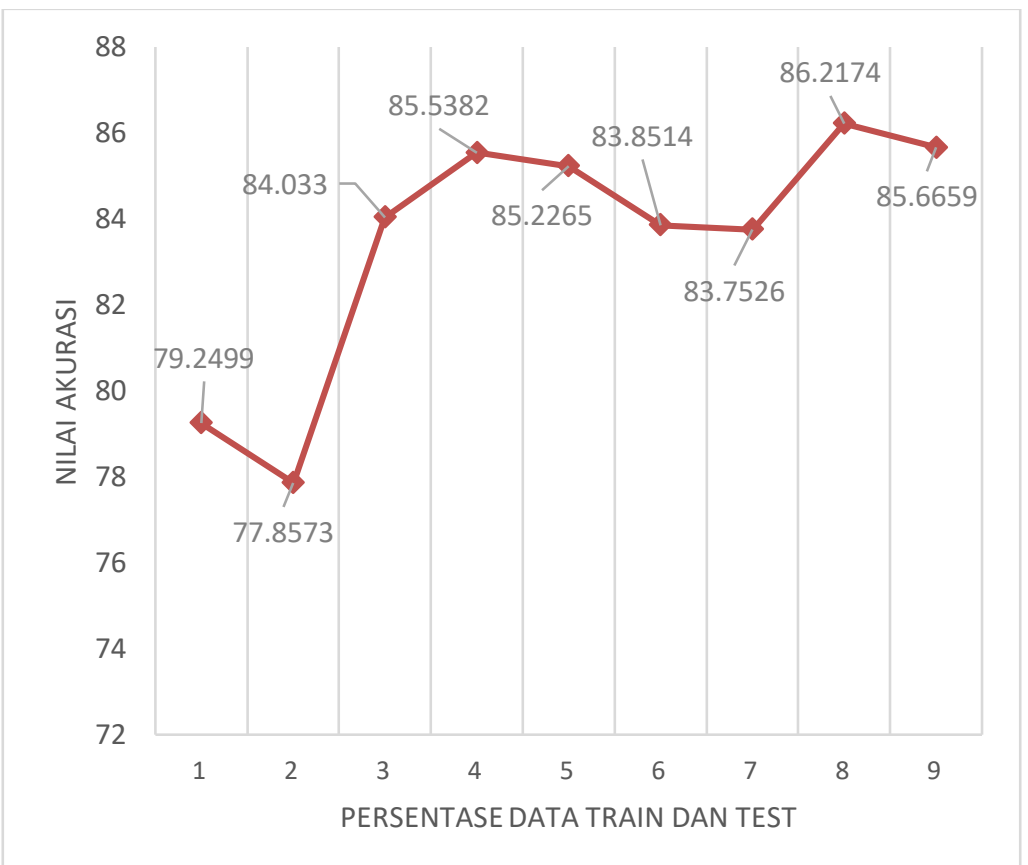

Gambar 9. Grafik Nilai Akurasi Tertinggi dengan RMSE untuk Setiap Persentase Data Train dan Test

Kondisi peramalan dengan nilai terendah yang dihasilkan dalam penelitian adalah persentase data train $30 \%$ dengan learning rate 0.9 dan arsitektur 2-1-1. Hasil evaluasi model diperoleh nilai MSE dan RMSE, 0.01919521 dan 0.10991967 untuk training set serta, 0.03502402 dan 0.18714707 untuk MSE dan RMSE dari test set. Berdasarkan dengan nilai MSE dan RMSE diperoleh nilai akurasi $94.326293 \%$ dan $76.180455 \%$. Waktu eksekusi yang dibutuhkan selama 403.71355259 second atau 6.728559 menit. Gambar 10 dan Gambar 11 menampilkan nilai akurasi terendah dari setiap persentase data train dan data test. 


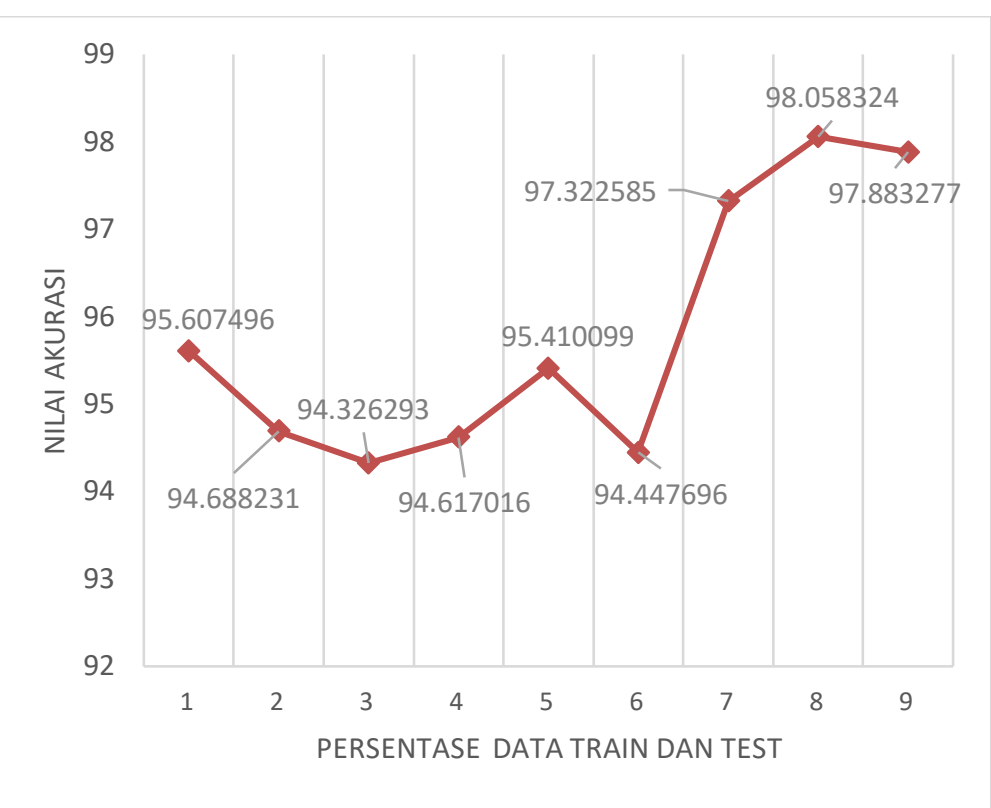

Gambar 10. Grafik Nilai Akurasi Terendah dengan MSE untuk Setiap Persentase Data Train dan Test

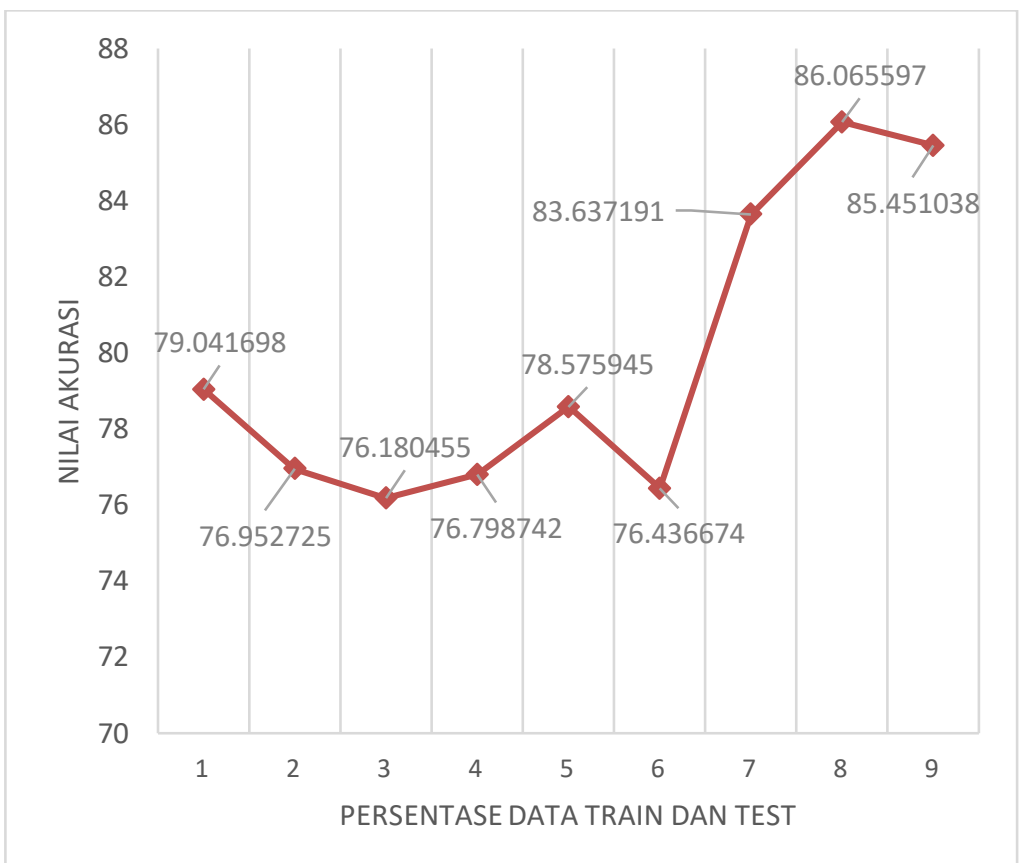

Gambar 11. Nilai Akurasi Terendah dengan MSE untuk Setiap Persentase Data Train dan Test

\section{Kesimpulan}

Berdasarkan hasil penelitian, metode MLP berhasil melakukan peramalan terhadap sessions dari website journal. Nilai akurasi terbaik yang berhasil diperoleh adalah 98.1004\% untuk MSE dan $86.2174 \%$ untuk RMSE. Akurasi terbaik diperoleh dari persentase data train $80 \%$ dengan learning rate 0.4 dan arsitektur $2-1-1$. Waktu eksekusi yang dibutuhkan adalah adalah 580.0651 second atau 9.667751 menit. Untuk penelitian lebih lanjut, disarankan menggunakan data penelitian yang berbeda.

\section{Daftar Pustaka}

[1] V. R. Sutrisno, "Analisis Forecasting untuk Data Penjualan Menggunakan Metode Simple Moving Average dan Single Exponential Smoothing: Studi Kasus PT Guna Kemas Indah."

[2] R. J. Hyndman, "Forecasting: An Overview," Int. Encycl. Stat. Sci., pp. 536-539, 2011, doi: 10.1007/978-3-642-04898-2_256.

[3] R. Ginting et al., "Peramalan dan faktor faktor yang mempengaruhi harga bawang merah di sumatera 
utara."

[4] B. Siregar, E. B. Nababan, A. Yap, U. Andayani, and Fahmi, "Forecasting of raw material needed for plastic products based in income data using ARIMA method," Proceeding - 2017 th Int. Conf. Electr. Electron. Inf. Eng. Smart Innov. Bridg. Futur. Technol. ICEEIE 2017, vol. 2018-Janua, pp. 135-139, 2018, doi: 10.1109/ICEEIE.2017.8328777.

[5] D. R. Chandra, M. S. Kumari, and M. Sydulu, "A detailed literature review on wind forecasting," Proc. 2013 Int. Conf. Power, Energy Control. ICPEC 2013, pp. 630-634, 2013, doi: 10.1109/ICPEC.2013.6527734.

[6] L. Zhuang, H. Liu, J. Zhu, S. Wang, and Y. Song, "Comparison of forecasting methods for power system short-Term load forecasting based on neural networks," 2016 IEEE Int. Conf. Inf. Autom. IEEE ICIA 2016, no. 61473174, pp. 114-119, 2017, doi: 10.1109/ICInfA.2016.7831806.

[7] G. De Luca and M. Gallo, "Artificial neural networks for forecasting user flows in transportation networks: Literature review, limits, potentialities and open challenges," 5th IEEE Int. Conf. Model. Technol. Intell. Transp. Syst. MT-ITS 2017 - Proc., pp. 919-923, 2017, doi: 10.1109/MTITS.2017.8005644.

[8] F. Guo, C. Y. Liu, B. Zhou, and S. Q. Zhang, "Spares consumption combination forecasting based on genetic algorithm and exponential smoothing method," Proc. - 2012 5th Int. Symp. Comput. Intell. Des. Isc. 2012, vol. 2, pp. 198-201, 2012, doi: 10.1109/ISCID.2012.201.

[9] J. Lian and L. Li, "Predictive Analysis of E-Commerce Enterprises Soft Operating Costs Based on Exponential Smoothing Technique," no. 1, pp. 1-5.

[10] X. Qin, C. Jiang, and J. Wang, "Online clustering for wind speed forecasting based on combination of RBF neural network and persistence method," Proc. 2011 Chinese Control Decis. Conf. CCDC 2011, pp. 2798-2802, 2011, doi: 10.1109/CCDC.2011.5968687.

[11] J. M. Nazzal, I. M. El-emary, S. a Najim, A. Ahliyya, P. O. Box, and K. S. Arabia, "Multilayer Perceptron Neural Network ( MLPs ) For Analyzing the Properties of Jordan Oil Shale," World Appl. Sci. J., vol. 5, no. 5, pp. 546-552, 2008.

[12] Y. S. Park and S. Lek, Artificial Neural Networks: Multilayer Perceptron for Ecological Modeling, vol. 28. Elsevier, 2016.

[13] A. B. HERMANIANTO, "Optimasi multi-layer perceptron pada model prediksi karakteristik musim hujan dan kemarau di kabupaten pacitan abdul basith hermanianto," 2017.

[14] T. Marwala, "Multi-layer Perceptron," Handb. Mach. Learn., no. 2001, pp. 23-42, 2018, doi: 10.1142/9789813271234_0002.

[15] S. C. Satapathy, A. Govardhan, K. S. Raju, and J. K. Mandal, "An Overview on Web Usage Mining," Adv. Intell. Syst. Comput., vol. 338, no. November 2014, pp. V-VI, 2015, doi: 10.1007/978-3-31913731-5.

[16] P. M. Chawan, "Web Usage Mining," no. June 2013, 2017.

[17] Z. M. Kesuma, "Feature Selection Data Indeks Kesehatan Masyarakat Menggunakan Algoritma Relief," Statistika, vol. 11, no. 1, pp. 61-66, 2011.

[18] S. E. Buttrey, “Data Mining Algorithms Explained Using R,” J. Stat. Softw., vol. 66, no. Book Review 2, 2015, doi: 10.18637/jss.v066.b02.

[19] G. M. Tinungki, "Metode Pendeteksian Autokorelasi Murni dan Autokorelasi Tidak Murni," vol. 13, no. 1, pp. 46-54, 2016.

[20] S. G. K. Patro and K. K. sahu, "Normalization: A Preprocessing Stage," Iarjset, no. April, pp. 20-22, 2015, doi: 10.17148/iarjset.2015.2305.

[21] C. Saranya and G. Manikandan, "A study on normalization techniques for privacy preserving data mining," Int. J. Eng. Technol., vol. 5, no. 3, pp. 2701-2704, 2013.

[22] Z. Alameer, M. A. Elaziz, A. A. Ewees, H. Ye, and Z. Jianhua, "Forecasting gold price fluctuations using improved multilayer perceptron neural network and whale optimization algorithm," Resour. Policy, vol. 61, no. September 2018, pp. 250-260, 2019, doi: 10.1016/j.resourpol.2019.02.014.

[23] H. K. Cigizoglu, "Estimation and forecasting of daily suspended sediment data by multi-layer perceptrons," vol. 27, pp. 185-195, 2004, doi: 10.1016/j.advwatres.2003.10.003.

[24] E. Eğrioğlu, Ç. H. Aladağ, and S. Günay, "A new model selection strategy in artificial neural networks," Appl. Math. Comput., vol. 195, no. 2, pp. 591-597, 2008, doi: 10.1016/j.amc.2007.05.005.

[25] M. Ettaouil and Y. Ghanou, "Neural architectures optimization and genetic algorithms," WSEAS Trans. Comput., vol. 8, no. 3, pp. 526-537, 2009.

[26] J. Gomez-avila, Adaptive PID Controller Using a Multilayer Perceptron Trained With the Extended Kalman Filter for an Unmanned Aerial Vehicle. Elsevier Inc., 2019.

[27] W. Setiawan and U. T. Madura, "Prediksi Harga Saham Menggunakan Jaringan Syaraf Tiruan Multilayer Feedforward Network dengan Algoritma," no. January, 2015, doi: 10.13140/2.1.3467.5525.

[28] N. P. Sakinah, I. Cholissodin, and A. W. Widodo, "Prediksi Jumlah Permintaan Koran Menggunakan 
Metode Jaringan Syaraf Tiruan Backpropagation,” J. Pengemb. Teknol. Inf. dan Ilmu Komput. Univ. Brawijaya, vol. 2, no. 7, pp. 2612-2618, 2017.

[29] S. Naduvil-vadukootu and R. A. Angryk, "Evaluating Preprocessing Strategies for Time Series Prediction Using Deep Learning Architectures," pp. 520-525, 2017.

[30] M. H. SAZLI, “A brief review of feed-forward neural networks," Commun. Fac. Sci. Univ. Ankara, no. January 2006, pp. 11-17, 2006, doi: 10.1501/0003168.

[31] G. P. Zhang and M. Qi, "Neural network forecasting for seasonal and trend time series," Eur. J. Oper. Res., vol. 160, no. 2, pp. 501-514, 2005, doi: 10.1016/j.ejor.2003.08.037. 